\title{
0 comércio de mapas na França e na Grã Bretanha durante o século XVIII*
}

\section{The map trade in France and Great Britain in the Eighteenth Century*}

\author{
MARY SPONBERG PEDLEY \\ William L. Clements Library \\ The University of Michigan \\ Ann Arbor, MI, 48109-1190 \\ mpedley@umich.edu
}

RESUMO Esse artigo analisa as formas de produção de mapas na França e na Inglaterra durante o século XVIII. Discute a formação e os mecanismos de atuação dos geógrafos e topógrafos, bem como os mecanismos de produção, reprodução e comércio de mapas na época.

Palavras-chave Cartografia, cartógrafos, comércio de mapas

ABSTRACT This article analyses the map production in France and England in the Eighteenth Century. Presents the training methods and the daily life of

\footnotetext{
* Artigo recebido em 05/02/2007. Autor convidado.

(Esse artigo foi escrito a partir das palestras dadas pela autora em 2001 enquanto a Fourteenth Nebenzahl Lectures em História da Cartografia na Newberry Library, Chicago, Illinois, USA. Essas palestras foram publicadas em The

Commerce of Cartography: making and marketing maps in eighteenth-century France and England. Chicago: The University of Chicago Press, 2005.

** Tradução de Clara Furtado Lins.
} 
geographers and surveyors, also the map's production, reproduction and trade at that time.

Key words Cartography, cartographers, map trade

\section{Os mapas na Sociedade do século XVIII}

Um vigoroso comércio de mapas entre a França e Inglaterra somente se desenvolveu após o fim dos turbulentos anos das guerras religiosas, quando ocorreu a estabilização política dos dois países. Tanto a Inglaterra quanto a França sofreram guerras civis que culminaram no restabelecimento da Coroa: Louis XIV na França (1661) e Charles II na Inglaterra (1660). Desde a ascensão desses dois monarcas até a Revolução Francesa, no final do século XVIII, ambas as nações, apesar de estarem muitas vezes em guerra uma com a outra ou mesmo com outras nações, desfrutaram de prosperidade crescente, da expansão comercial e do aumento do consumo. A estabilidade política aumentou as oportunidades educacionais. Um público cada vez mais alfabetizado e próspero necessitava de mais mercadorias, incluindo os mapas. Esses estavam em todos os lugares: nas vitrines das gráficas, nas salas de aula, nos cafés, em jornais, emoldurados nas paredes das casas e impressos em Atlas nas bibliotecas particulares. Decoravam os móveis, os baralhos, os jogos de tabuleiro, os leques das senhoras e as canecas de café. Estavam ao alcance inclusive dos analfabetos.

A ubiqüidade dos mapas no século XVIII era a herança da produção em massa que se tornou possível devido às técnicas de gravação e impressão feitas em placas de cobre, que reproduziam até mil mapas a partir de uma única placa. Mas os mapas impressos no século XVIII variavam dos produzidos industrialmente no século XX de uma maneira significativa: era o trabalho de um indivíduo, não de uma companhia. Um único cartógrafo reivindicava a responsabilidade sobre seu conteúdo e, geralmente, publicava um artigo para acompanhar o mapa e explicarsua criação. Se um mapa não possuía o nome de seu cartógrafo exposto, o comprador ainda poderia ter certeza de que o mapa havia sido copiado do trabalho de apenas cartógrafo individual. Na Inglaterra e na França, o cartógrafo e sua reputação eram o centro do comércio de mapas. Um comprador não queria apenas um mapa da Europa, mas queria o mapa da Europa de Delisle ou de Moll. O nome do cartógrafo possuía valor comercial muito depois que ele estivesse morto e seus mapas desatualizados.

\section{Quem eram os cartógrafos?}

Os cartógrafos da Inglaterra e da França estavam divididos em dois grupos: topógrafos e geógrafos. O topógrafo trabalha com uma escala 
maior, ao ar livre, fazendo levantamentos topográficos que resultavam em mapas desenhados a partir da observação pessoal e de medidas tomadas por ele. 0 geógrafo (pois "cartógrafo" não era um termo usado até o século dezenove) ficava no ateliê e produzia mapas numa escala menor, realizados a partir da compilação dos levantamentos topográficos, dos mapas publicados previamente, dos mapas manuscritos e das descrições verbais de viajantes e exploradores. 0 treinamento de ambos os grupos se parecia, de várias maneiras, com o treinamento de artesões de outros setores: aprendizado com um membro da família ou com alguém de relacionamento estreito, seguido por trabalho independente por sua própria conta, recebimento de herança de um estoque de mapas, papéis, e placas de cobre. Ligações familiares eram muito importantes, pois ligações de sangue, casamento e bons pais criavam uma rede de famílias que mantinham tanto a reputação, quanto o valor comercial do estoque.

\section{Cartógrafos franceses}

Na França, topógrafos ou geógrafos publicavam seus próprios trabaIhos, confiando nos gravadores apenas para o trabalho, não para o capital. Topógrafos eram treinados tanto pelo sistema privado de aprendizado, quanto pelo exército francês, cujas unidades de engenheiros-geógrafos supriam o mercado com vários produtores de mapas. Depois de deixarem 0 exército, engenheiros-geográficos, como Georges Louis Le Rouge ou RochJ oseph J ulien, montaram uma loja como muitos compiladores de mapas e editores. J ulien abriu a primeira loja internacional de mapa em Paris, no Hotel de Soubise, no distrito de Marais, onde ele era também o intendant des batiments ${ }^{1}$ para o Príncipe de Soubise. Ele vendia seus próprios mapas e também aqueles de outros geógrafos franceses, da mesma forma importava mapas, para citar apenas alguns, de Andrew Dury, em Londres; Gosse e Pinet, em Hague; Matthew Seutter, em Augsburg e dos Homann Heirs, em Nuremberg. Ele dizia que mandava papel bom de Auvergne para as firmas alemãs imprimirem seus mapas para o mercado francês. ${ }^{2}$ Regularmente, trocava correspondências com os editores de mapas londrinos, como William Faden. ${ }^{3}$ Georges Le Rouge agia no mercado internacional da mesma maneira, vendendo tanto mapas franceses quanto cópias de mapas ingleses.

[NT] Intendant des batiments: Pessoa encarregada de administrar um bem, uma casa, ou um conjunto de residências.

2 Observations. In: J ULIEN, Roch-J oseph. Nouveau Catalogue de cartes géographiques et topographiques.... Paris, 1763.

3 PEDLEY, Mary. The Map Trade in the late eighteenth century: Letters to the London map sellers J efferys and Faden. Oxford: Voltaire Foundation, 2000, passim. 
Para disponibilizar uma grande variedade de mapas, comerciantes de mapas como J ulien e Le Rouge confiavam no géographes de cabinet, os chamados "geógrafos de gabinete". Na França do século XVIII, apenas algumas poucas famílias dominavam essa maneira de produzir mapas. Durante todo esse século, a família de Claude Delisle foi proeminente no campo da cartografia. Seus filhos, Guillaume, o geógrafo, e J oseph-Nicolas, 0 astrônomo, providenciaram ao mercado mais de cem mapas entre $1700 \mathrm{e}$ 1760. Esse trabalho deu a Guillaume Delisle o título de premier géographe du roi (primeiro geógrafo do rei), tendo produzido mapas e informações geográficas para o Regente, Philippe d'Orléans, e Louis XV; como seu pai, Claude, havia feito para Louis XIV. O genro de Delisle, Philippe Buache, de forma similar, serviu a Louis XVI e recebeu o mesmo título, que passou para seu sobrinho, J ean Nicholas Buache de la Neuville, que trabalhou no Dépôt dês Cartes et Plans de la Marine (Departamento de Cartas e Planos da Marinha) até a Revolução Francesa. Deslile e Buache, por essas razões, viraram nomes proeminentes na cartografia durante o século XVIII. Outros cartógrafos eminentes foram Robert de Vaugondy, pai e filho, ambos géographes du roi e J ean Baptiste Bourguignon d'Anville, que foi o premier géographe du roi entre Philippe Buache e J ean Nicholas Buache de la Neuville. 0 nome de qualquer desses geógrafos em um mapa com a marca de aprovação real funcionava como um comprovante de "bom mapeamento" para o comprador. Enquanto ambos vendiam seus mapas na França e no exterior, os mesmos eram ao mesmo tempo muito copiados e plagiados por outros.

Como eles adquiriram essas reputações formidáveis? Emergindo de uma classe média que ficava cada vez mais rica, eles eram os produtos de um sistema educacional organizado predominantemente por ordens religiosas, que incluía a Matemática e a Ciência como parte do seu currículo básico. Particularmente, os J esuítas davam ênfase à Geografia tanto quanto à História, em um currículo no qual utilizavam mapas, atlas e globos para ensinarem o mundo natural e político. Ao utilizarem uma abordagem Cartesiana, geógrafos franceses como Delisle, Robert de Vaugondy e d'Anville começaram com uma grade de coordenadas de longitudes e latitudes e reuniram mapas de várias fontes diferentes: mapas antigos, relatos de exploradores, relatos de viagens e levantamentos topográficos manuscritos. Dessas fontes, os geógrafos estabeleceram os contornos das costas, as fronteiras, as maiores cidades e as características topográficas e geográficas. Para acompanharem seus mapas, eles escreveram Memórias descrevendo suas fontes e explicando os métodos utilizados para fazer as cartas. Eles apresentaram seus trabalhos para os membros letrados da sociedade na Académie des Sciences (Academia de Ciências) e na Académie des Incriptions et Belles Lettres (Academia de Belas Letras), nas assembléias de cientistas amadores e nos de patrocinadores nobres que examinavam 


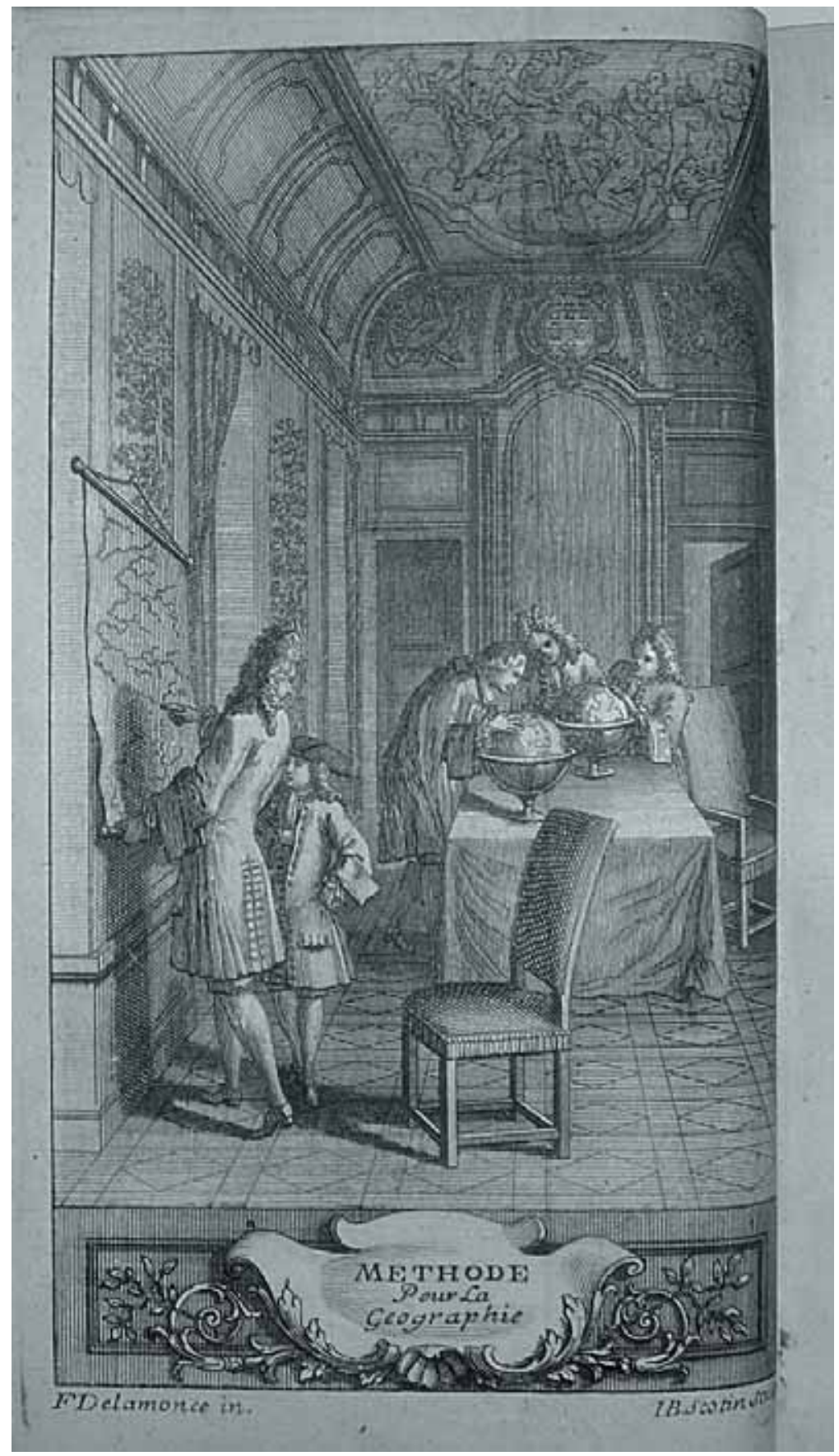

Figura 1

l'Abbé Lenglet Dufresnoy, Méthode pour étudier la géographie. Paris, 1741. frontispiece. (com a permissão de William L. Clements Library, the University of Michigan). C2 1741 Le. 
e debatiam os resultados. Uma aproximação cuidadosa da confiabilidade dos fatos geográficos estava na essência do trabalho de um geógrafo do século XVIII; ele não tinha medo de admitir o que ele não sabia. A revelação pública dos métodos de trabalho dos geógrafos franceses dava abertura às críticas ao seu trabalho, mas também aumentava sua reputação científica. Apesar de eles viajarem muito pouco, raramente deixavam Paris, seus mapas eram surpreendemente precisos, como descobriram os oficiais de Napoleão, quando utilizaram o mapa do Egito, de d'Anville (1765), durante a Expedição Egípcia, no final do século. "Apenas pela força de sua crítica, ele assinalou com uma justeza que nos confundia, a posição das vilas antigas, as vilas e os cursos de canais que ele jamais visitou". ${ }^{4}$

Géographes de cabinet, como Delisle e d'Anville, publicavam e vendiam seus próprios mapas em suas próprias casas, anunciando-os em jornais e periódicos do dia. Eles faziam trocas com comerciantes de mapas estrangeiros e contavam com a renda da venda dos mapas para reembolsá-los do demorado e custoso trabalho de compilação de mapas, a parte mais dispendiosa da produção cartográfica. Para aumentar suas rendas, eles ofereciam cursos públicos de Matemática, História e Geografia e dependiam das modestas pensões reais oriundas de seus compromissos como géographes du roi, um título honorífico recebido após a apresentação de uma obra prima cartográfica para o Rei. Um géographes du roi poderia ter certeza que o monarca havia visto, entendido e aprovado o trabalho do cartógrafo, pois os monarcas Bourbon eram muito interessados em mapas. $\mathrm{Na}$ época de Louis XIII, eles encorajavam atividades cartográficas no reino, disponibilizando suporte financeiro e incentivando o conhecimento. Louis XIV trouxe 0 astrônomo J ean Dominique Cassini, de Bologna, para trabalhar no problema da longitude, que resultou em um levantamento topográfico da França, que foi continuado por sua família durante quatro gerações, até estar completo no final do século XVIII. O neto de Louis XIV, Louis XV, já desfrutava de uma educação geográfica, quando seu tio, Philippe d'O rléans, o Regente, que foi aluno de Claude Delisle, apontou Guillaume Delisle como um dos tutores desse jovem rei. Louis XVI teve como mestre o genro de Delisle, Philippe Buache, cujas lições permitiram que o rei participasse ativamente da preparação das viagens francesas de exploração no final do século XVIII.

Geógrafos, ou seja, pessoas que compilavam mapas, dominavam o mercado de mapas na França; eles produziam o grosso do material para a produção de mapas de média escala, contratavam os gravadores, pro-

4 "Par la seule force de sa critique, il a assigné avec une justesse qui nous confondait, la position des villes anciennes, celle des villages et le cours des canaux d'un pays qui'il n'avait jamais visité". BROC, Numa. La Géographie des Philosophes. Paris, 1974, p.34. Elogio similar foi proferido pelo cartógrafo ingles, J ames Rennell, ao mapa da Índia de d'Anville's. BROC, Numa. La Géographie des Philosophes, p.89: 
curavam o papel e, algumas vezes, até imprimiam seus próprios mapas. Apesar de que alguns gravadores de mapas terem sido bem sucedidos 0 bastante para tornarem-se ed itores, eles ainda contavam com os geógrafos para providenciarem o conteúdo cartográfico de seus trabalhos. Um dos exemplos mais bem sucedido foi J ean Lattré, graveur du roi (gravador do rei), que contratou os geógrafos Rigobert Bonne e Giovanni Antonio Rizzi Zannoni para prepararem mapas para suas publicações, como o Atlas Moderne (1762).

\section{Cartógrafos ingleses}

$\mathrm{Na}$ Inglaterra, onde os mapas eram abundantes e mais baratos, 0 mercado era dominado por gravadores. O sistema educacional francês acessível ao público, dirigido por ordens religiosas, que incluía as Ciências, não existia na Inglaterra. 0 padrão de educação formal inglês era diferente do francês, pois o Estado não interferia na educação ou no treinamento formal, exceto de oficiais do exército e de engenheiros. Além disso, Matemática e Geografia básica eram consideradas matérias básicas, essenciais para comerciantes e oficiais mecânicos e não para a gentry, que seguia um currículo clássico. Escolas de caridade ou aulas privadas eram os únicos recursos para aqueles interessados em estudar a matéria mais importante para tornar-se um geógrafo: Matemática prática. Essa matéria era buscada normalmente apenas por aqueles que desejavam entrar no comércio.

Em Londres, foram o comércio de livros impressos e a fabricação de instrumentos científicos que produziram os geógrafos ingleses. Treinados como gravadores ou feitores de instrumentos, cartógrafos como Hermann Moll, Emanuel Bowen ou Thomas J efferys aprenderam o negócio de mapas rapidamente, contando com a importação de idéias geográficas do continente, onde geógrafos franceses, alemães e italianos estavam mais adiantados. Para os levantamentos topográficos atualizados das llhas B ritânicas, eles contaram com uma frágil rede de topógrafos, que se beneficiavam do sistema de aprendizes e/ou do ensino particular. Mapas ingleses, quando compilados numa escala média, eram produzidos sem a Memória justificativa; ocasionalmente uma anotação podia ser achada no próprio mapa. Com poucas exceções (J ohn Senex, Henry Popple, Sir J oseph Moxon), cartógrafos ingleses não eram membros da Royal Society, apesar dos seus trabalhos às vezes serem ali apresentados. Como sua instituição irmã em Paris, a Royal Society se preocupava com assuntos e projetos que visavam encontrar um meio preciso para determinar as longitudes e o formato da terra, mas não tinham fundos nem interesse em empreendimentos estritamente cartográficos. Seu porta-voz, os Philosophical Transactions, publicou apenas dois artigos sobre mapas durante todo o século, em oposição ao 
artigo mensal de mapas no J ournal des Scavans, o órgão da Académie des Sciences.

Os compromissos do Geógrafo do Rei, Hidrógrafo do Rei, Corógrafo do Rei não eram acompanhados por um salário regular, nem a Coroa ou - Parlamento estavam dispostos a darem apoio para as pesquisas e a med ição do reino. Isso não quer dizer que os monarcas não estavam interessados em mapas: Charles II, Príncipe George da Dinamarca (cônjuge da Rainha Anne), George Il e seu irmão, o Duque de Cumberland, e George III eram todos aficionados com mapas, os colecionavam e os utilizavam em suas funções públicas e privadas. Mas suas funções públicas eram limitadas pelo Parlamento, que não providenciou apoio financeiro para o ato de mapear até o final do século, quando ocorreu o mapeamento das forças militares (Ordnance Survey) da Inglaterra. O cartógrafo inglês, então, era um gravador cujas raízes estavam no mundo do comércio, não no mundo dos estudos. Ele estava atado ao mercado para financiar seu empreendimento cartográfico.

\section{Onde comprar mapas}

Não importa quem fazia os mapas, eles eram baratos e podiam ser obtidos facilmente com o próprio cartógrafo, ou com um impressor ou um vendedor de livros. Para comprar um mapa em Paris ou Londres, você não precisava ir mais longe do que o distrito onde se vendiam livros em ambas as capitais. Em Londres, os estabelecimentos que vendiam mapas estavam localizados em linha ao norte do rio Tamisa, se espalhando das docas de Wapping no leste, atrás da Torre de Londres, em torno da Catedral de St. Paul, junto da Fleet Street e da Strand, através do Soho e de St. Martin no Field, até Westminister Hall, no oeste. Esses eram os bairros dos comerciantes de livros e impressores de textos, com quem os gravadores de mapas e os cartógrafos estavam intimamente conectados. Em Paris, os vendedores de mapas se juntavam ao sul do rio Sena, perto dos vendedores de livros, nas ruas estreitas da rua St. J acques, perto da Universidade. Eles também ocupavam o quai des Augustins e se agrupavam junto do quai de l'Horloge, perto dos tribunais, no lado norte da ilha de la Cité. Alguns mantinham lojas ao norte do Sena, em volta de St Germain l'Auxerrois, perto do Louvre; outros aproveitavam alojamentos custeados pelo estado nas Galerias do Louvre. Em ambas as capitais, a proximidade das lojas e a concentração de numerosos cartógrafos oferecia ao consumidor muitas escolhas. Nesse mercado competitivo, o que o consumidor procurava em um mapa?

5 [NT] Corógrafo é o especialista em Corografia, que é o estudo ou descrição geográfica de um país, região, província ou município. 


\section{0 que queriam os consumidores de mapas}

Apesar da estabilidade política geral durante o século XVIII, havia contínuos conflitos militares na Europa continental entre as super-poderosas casas dos Habsburgos, Hanover e Bourbon, conflitos que despertavam 0 apetite dos consumidores. Comandantes militares, ministros do governo e o público seguiam as guerras pelos mapas, os quais traziam notícias e destilavam informações militares de uma maneira simples e fácil de compreender. Mapas também anunciavam os resultados de explorações e o descobrimento de terras e águas até então desconhecidas para os europeus. Mapas delineavam e formavam na mente européia os contornos e os terrenos de suas colônias no exterior assim como terras e territórios perto de casa. Eles providenciavam ao usuário um estímulo para investir no colonialismo crescente e o espírito de aventura prevaleceu na Inglaterra e na França.

J unto com as notícias de guerras e explorações, "a Filosofia Natural" ou ciência experimental também despertava interesse pelos mapas. As contribuições de Galileo Galilei, Francis Bacon, René Descartes e Isaac Newton mudaram radicalmente a maneira como as pessoas entendiam seu lugarno universo. 0 estudo do mundo natural, por meio do microscópio, e do mundo extraterrestre, pormeio do telescópio, moldou três novas idéias sobre a posição, o formato e o tamanho da terra. Primeiro, que a terra estava inserida no sistema solar de Copérnico, no qual o sol era o centro. Segundo, que a terra era achatada nos pólos e não uma esfera perfeita. Terceiro, que era possível medir com precisão o tamanho da terra e determinar a localização exata de qualquer lugar no globo. Essas três idéias foram desenvolvidas, examinadas, debatidas e aperfeiçoadas durante o século XVIII.

Os resultados dessa pesquisa científica modificaram a aparência dos mapas ao londo do século. Com a mudança na percepção e no entendimento da paisagem, os cartógrafos e topógrafos foram encorajados a experimentar e aperfeiçoar as representações das formas topográficas. Gravadores e impressores de placas de cobre foram encorajados a tentarem técnicas diferentes para representarem essas formas graficamente. 0 desenvolvimento de linhas de contorno para mostrarem altura e profundidade, o uso da gradação das cores para ilustrar água, pântanos e brejos e as técnicas abrasivas de gravação para definir os formatos das terras criaram mapas que aparentavam ser diferentes dos mapas do século anterior.

A mudança mais óbvia, contudo, estava na ornamentação. Características decorativas, que antes faziam parte do conteúdo dos mapas, desapareceram gradualmente ou passaram para as cartelas dos mapas. Os navios e os peixes exóticos foram tirados dos oceanos; as terras incógnitas (terrae incognitae) foram nomeadas dessa forma e, de maneira atrativa, permaneceram vazias, destituídas de pessoas estranhas em seu trajes não familiares (ou mesmo sem roupas). O mapa do século XVIII refletia a relutância de 


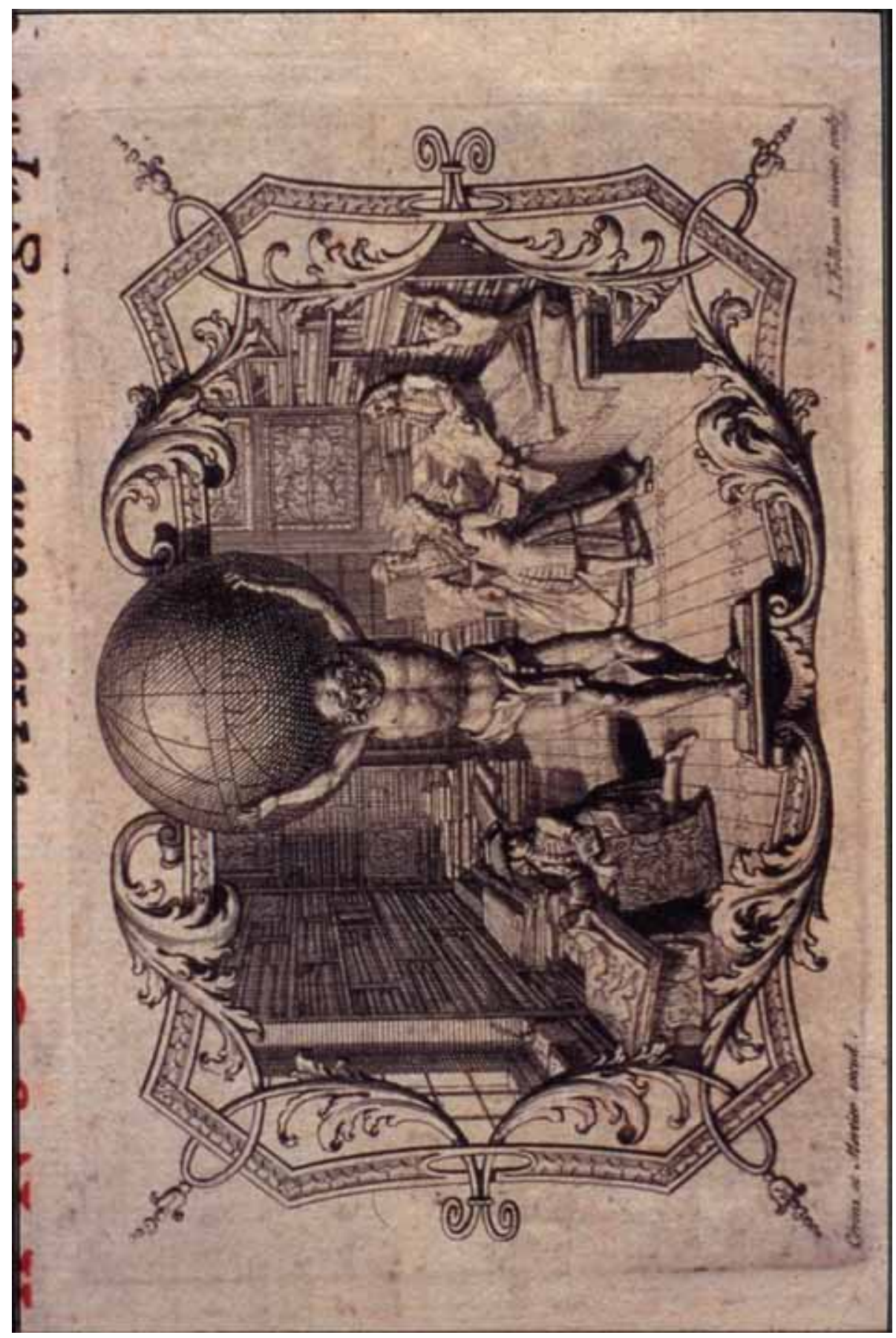

Figura 2

Vignette of mapsellers' shop, from title page G. Delisle, Atlas Nouveau, Amsterdam: Covens and Mortier, 1721. (com a permissão de William L. Clements Library, the University of Michigan) 
descrever qualquer característica como "fato" se ele era baseado em relatos pouco substantivos; os espaços precisavam ser deliberadamente medidos, suas locações confirmadas por pesquisas e observações astronômicas. A era do mapa "científico" havia nascido, e a era dos anúncios vinha logo a seguir. Mesmo se o mapa não fosse inteiramente "científico" (observado e medido) em sua construção, seu título assegurava ao comprador que era baseado nas "mais recentes observações astronômicas".

O consumidor de mapas sem acesso às observações originais não tinha como checar se a informação no mapa estava correta ou não, especialmente se a área desenhada era um lugar distante. Alguns lugares, tão longínquos quanto a lua para os europeus, eram assuntos de debates intelectuais, enquanto relatos de viajantes e expedições cientificas eram avaliadas por sua veracidade. A geografia da América do Norte e sua relação com a Ásia e o Pacífico continuaram como uma fonte de admiração e como mistério cartográfico. A Califórnia, que havia sido separada da América do Norte nos mapas do final do século dezessete, foi gradualmente rejuntada ao continente no século XVIII, enquanto as explorações jesuítas revelavam o formato da costa. Mas a vasta parte não explorada do noroeste do continente continuava a seduzir os geógrafos. O contínuo desejo europeu da existência de uma rota fluvial entre o Atlântico e o Pacífico, uma Passagem Noroeste, foi traduzida nos mapas em uma variedade de lagos, rios e oceanos continentais. Geógrafos mais cuidadosos deixaram a área vazia.

Se o usuário do mapa não conseguia estimara precisão geográfica dos lugares distantes, o mesmo não ocorria em relação aos lugares próximos de casa. Para os consumidores de mapas, precisão significava a escrita correta dos nomes dos lugares, o que não era uma tarefa fácil em uma época onde a escrita ainda não era padronizada e que variava de região para região. Também as variações locais de pronúncia poderiam complicar o trabalho do cartógrafo. Fora da Inglaterra e da França, essa questão ficava mais complicada quando os europeus tentavam dar sentido às palavras estrangeiras, fossem dos indígenas da América ou dos do Oriente. A ortografia dos nomes de lugares estrangeiros virou fonte de muita discussão entre os geógrafos.

Precisão também significava legibilidade e a aparência do mapa geralmente submetia a precisão geográfica. Correspondência entre os cartógrafos e seus clientes no século XVIII nos diz que os clientes queriam seus mapas "grandes e bonitos," em um papel bonito e com uma bonita moldura. O Méthode pour l'étudier la géographie, do abade Lenglet-Defresnoy, um guia para compras de mapas, dava ênfase à organização da gravação e à legibilidade das letras como aquilo que se deseja (desiderata) nos mapas. Cartógrafos, como Robert de Vaugondy, queriam gravadores que, em seus mapas, produzissem letras balanceadas e legíveis e se recusavam a pagar gravadores se o trabalho não estivesse bom. J oseph Nicolas De- 
lisle entendia o papel estético do gravador e o valor de um bom desenho: “... não é suficiente que os mapas sejam curiosos ou novos ou pelo menos interessantes e úteis ao progresso da geografia, como eu me proponho a fazê-los; mas que eles tenham ainda a vantagem de dar prazer aos olhos sendo gravadas com gosto e nitidez...". ${ }^{6}$

A preocupação com a ortografia e com o capricho dominava a crítica contemporânea de mapas, seguida de perto pela precisa localização. Para o geógrafo, localização significava as coordenadas de longitude e latitude. Para o comprador de mapa comum, significava em que lado da estrada ou do rio ficava um lugar, especialmente se esse lugar fosse seu lar.

A linguagem de um mapa poderia determinar seu sucesso comercial. Alguns cartógrafos eram aconselhados a darem dois títulos aos mapas, um na língua européia e outro em latim "para facilitar aos estrangeiros". ${ }^{7}$ Outros cartógrafos achavam que o latim poderia ser uma linguagem universal para os mapas, principalmente para os mapas alemães. ${ }^{8}$ Cartógrafos como LeRouge especializaram-se em reproduzir mapas ingleses para 0 mercado francês e ocasionalmente para os europeus, acrescentando títulos em alemão.

Compradores de mapas procuravam mapas copiados ou feitos por um geógrafo com boa reputação, um cujo nome estivesse associado a uma Academia, uma Sociedade ou um patrocínio real. Eles queriam mapas legíveis, que poderiam enfeitar as paredes e que continham algo novo, mesmo se o "novo" não pudesse ser diferenciado do velho.

\section{0 custo dos mapas}

Um mapa impresso, gravado em uma única placa in quarto ou in folio estava bem dentro dos padrões do que uma pessoa poderia precisar ou querer. Por exemplo, na Inglaterra do início do século, um mapa in folio (i.e., $45 \mathrm{X} 60 \mathrm{~cm}$ ) custava entre seis pences e um xelim; já no meio do século, esse preço aumentou entre um e três xelins. Um mapa com várias folhas, como o mapa da América, de oito folhas, de J ohn Mitchell, poderia custar entre um guinéu (uma libra e um xelim) e três xelins (três libras, três xelins). Um Atlas, com cinqüenta a cem mapas, poderia custar de três a sete libras. ${ }^{9}$

6 “... il ne suffit pas que les cartes soit curieuses et nouvelles ou pour le moins interessantes et utiles au progréz de la géographie, comme je me propose de les faire; mail il est encore avantageux qu'elles plaisent aux yeux étant gravées avec gout et netteté..." Paris: Bibliothèque de l'O bservatoire, Ms. B.1.7 (XII), J N Delisle to J acques Bellin, 24 October 1752.

7 Paris: Archives nationales, MAR 2J J /60 (21). Louis Renard, Amsterdam, to Guillaume Delisle, Paris, c.1706.

8 DE VAUGONDY, Didier Robert. Atlas Universel. Paris, 1757, Préface, "Essai sur I'histoire de la géographie", p.14a.: "Comme les travaux de ces Scavans [les Homans] ne doivent pas être renfermés dans l'enceinte de l'empire, ils jouiroient d'une plus grade réputation, s'ils étoient publiés en latin; d'ailleurs, quel avantage ne retireroient point de leurs lumières beaucoup de scavans qui sont étrangers dans la langue allemande".

9 A libra inglesa era dividida em 20 xelins, cada xelim em 12 pences. O guinéu, uma medida monetária inglesa comum, equivalia a uma libra e um xelim. 


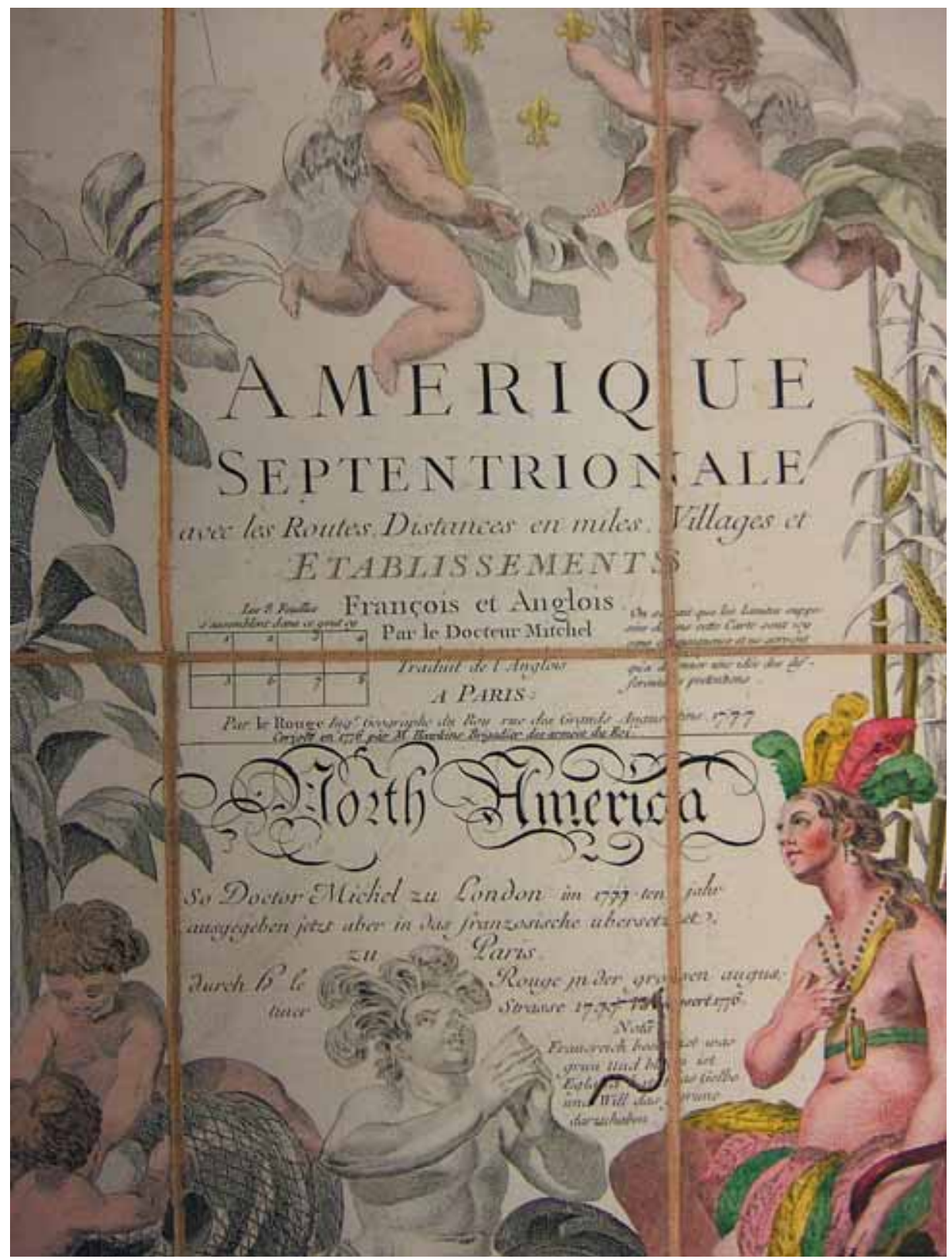

Figura 3

J ohn Mitchell, Amérique Septentrionale avec les routes, distances en miles, villages et etablissements François et Anglo is / par le Docteur Mitchel traduit de l'Anglois. Published in Paris, in French, by Georges Le Rouge, quai des Augustins, 1777. (com a permissão de the William L. Clements Library, the University of Michigan. Atlas H-2). Em Paris, Le Rouge publicou a tradução francesa do influente mapa da américa do Norte, de J ohn Mitchell. 
Para colocar esses preços no contexto atual, considere os salários de trabalhadores que poderiam utilizar ou querer mapas tais como capitães do exército, que precisavam se abastecer com mapas para suas funções. Quando a serviço, o capitão da infantaria poderia receber dez xelins por dia; seu colega na cavalaria recebia uma libra, seis xelins e seis pence por dia. ${ }^{10}$ Com o preço de um xelim ou dois, os mapas estavam ao alcance desses militares, custando mais ou menos $4 \%$ do salário do dia. Para 0 gravador que havia cortado o mapa no cobre, o produto de seu trabalho era mais caro: um gravador que tivesse completado seu aprendizado poderia receber trinta xelins por semana (cinco xelins por dia). Para ele, o mapa representava mais ou menos $20 \%$ do seu salário por dia. Contudo, quando completamente empregado; o melhor gravador poderia receber metade de um guinéu (dez xelins, seis pence) por dia; para ele um mapa poderia ser apenas $10 \%$ de seu ganho diário. ${ }^{11}$

Para a classe de pessoas que freqüentemente comprava livros, impressões e mapas, esses preços eram irrisórios. Entre as classes mercantis, poderia se esperar que as propriedades valessem entre $£ 50.000$ até f500.000, tão grandes eram os lucros com a troca de escravos, tabaco, açúcar, contratos governamentais e investimentos em ações e terras. ${ }^{12}$ Nobres, como o Conde de Kildare, comandavam uma pequena fortuna em aluguéis, que no seu caso chegava a atingir a quantia de $£ 15.000$ por ano. Sua mulher, Emily Lennox, filha do Duque de Richmond, trouxe um dote de $£ 10.000$ ao casamento. ${ }^{13} \mathrm{O}$ Rei da Inglaterra não era necessariamente o homem mais rico da nação, mas sabemos que o gosto por mapas de George III significava que seus gastos com livros e mapas eram perto de $£ 1.000$ porano, crescendo para $f 1.500$ por ano depois de $1770 .{ }^{14}$ Para eles, o custo de um mapa não era diferente do de um baralho (1 ou 2 xelins por baralho), ou de um lugar na galeria no teatro, que custava 1 xelim, ou de algumas ${ }^{15}$ maçãs por dois xelins e cinco pence. Era mais barato que uma libra de chocolate que custava cinco xelins.

$\mathrm{Na}$ França, os mapas eram mais caros para aqueles que precisavam deles e para aqueles que os fabricavam. Um mapa custava entre 10 e 20 sous ( $1 / 2$ de um livre) no começo do século, e seis livres no final do século, apesar de que fosse típico um ou dois livres pormapa de uma folha in folio. ${ }^{16}$ Atlas e globos constituíam uma categoria diferente de itens luxuosos pois

10 CURTIS, Edward. The Organization of the British Army in the American Revolution. Yale, 1926, p.159.

11 CAMPBELL, R. The London Tradesman. London, 1747, p.114.

12 HANCOCK, David. Citizens of the world. Cambridge, 1995, p.383-385.

13 TILLYARD, Stella. The Aristocrats, 1994, p.50-51.

14 BROOKE, J ohn. The Library of George III, Yale University Library Gazette, New Haven, n.52, p.38-39, 1978.

15 [NT] A medida utilizada pela autora para as maçãs foi o bushel, que é uma medida de capacidade para frutas cereais, que corresponde na Inglaterra a 36,367 litros e nos EUA a 35,328.

160 livre francês era similar à libra inglesa e se dividia em 20 sous, cada sou valia 12 deniers. A unidade corrente mais alta era o ecu, que geralmente valia 3 livres e o Louis de ouro de 24 livres. 
eles possuíam preços altos, geralmente acima de cem livres. Mas um mapa não estava fora do alcance de oficiais do exército, que ganhavam 1.200 livres por ano [ = 3 e 1/3 livres por dia]; um mapa custava perto de $30 \%$ do seu ganho diário. Para os que trabalhavam com tapeçaria e ganhavam 12 livres por semana, ou 2 livres por dia, uma mapa era $50 \%$ do seu salário diário; isso era quase o mesmo para um impressor, que podia receber até 13 livres, um sou e 6 denier por semana. Mapas eram caros quando comparados com os gastos do dia-a-dia; por um livre, um mapa era mais caro do que um par de sapatos, o dobro do preço de um dia de aluguel; quatro vezes o preço de um café da manhã. ${ }^{17}$

Mas para a classe que comprava livros, essas quantias pareciam completamente insignificantes. A nobreza e a aristocracia contavam com a renda de 4.000 a 50.000 livres por ano. Viver da maneira que sua classe pedia - mantendo casas na cidade e no campo, roupas para a corte, serventes, cavalos e carruagens - requeria a quantia de 10.000 livres por ano. Uma renda de 4.000 a 10.000 livres por ano ainda permitia darem jantares algumas vezes por mês, mantendo alguns serventes e cinco ou seis cavalos. A renda deles provinha das terras que possuíam e de pensões pagas pelo Rei se eles tinham conexões com a corte. ${ }^{18}$ Até os oficiais do exército esperavam um complemento às suas rendas de outras fontes: terras, aluguéis, heranças familiares. Para essa classe, mapas, atlas e globos constituíam consumo necessário para a construção de uma biblioteca particular e eram símbolos de status e grande luxe.

O comércio de mapas na Inglaterra e na França no século XVIII era uma indústria em expansão. Enquanto a educação se popularizava e a riqueza crescia, a demanda de mapas aumentava. Essa demanda foi atendida por geógrafos e topógrafos, que produziam novas informações geográficas, e por gravadores e impressores, que perceberam que, copiando mapas alheios, poderiam ter um lucro maior, diminuindo o custo de produção. À medida que os membros das famílias dominantes na França morriam, seus estoques de mapas foram sendo comprados por editores, como Dezauche, Desnos e Delamarche, que consolidaram esses fundos geográficos em grandes e diversas casas de publicação. Similarmente na Inglaterra, estoques de placas e mapas eram vendidos ou adquiridos por um pequeno número de gravadores, como William Faden e J ohn Cary, que, gradualmente, tomaram conta de grande parte do mercado. Estava tudo pronto para o aparecimento das grandes casas de publicação cartográficas no século XIX. 